\title{
Pengaruh Organisasi Terhadap Mahasiswa Universitas Riau
}

\author{
${ }^{1}$ Halimatus Sa'diyah, ${ }^{2}$ Kasful Anwar US \\ 1-2 Jurusan Ekonomi Syariah, Fakultas Ekonomi dan Bisnis Islam, Universitas Negeri Sulthan Thaha \\ Saifuddin Jambi
}

Article history

Received: 02-3-2021

Revised: 10-4-2021

Accepted: 11-05-2021

*Corresponding Author: Halimatus Sa'diyah, Kafsul Anwar US, Jurusan Ekonomi Syariah, Fakultas Ekonomi dan bisnis Islam,

Universitas Negeri Sulthan

Thaha Saifuddin Jambi

Email:

halimahjambi88@gmail.c $\underline{\mathrm{o}} \underline{\mathrm{m}}$
Abstrak: Penelitian ini dilakukan di Universitas Riau tepatnya di sekretariat BEM Universitas Riau. Perbedaan pandangan antara mahasiswa yang mengikuti organisasi dan mahasiswa yang tidak mengikuti organisasi yang menyebabkan penulis tertarik meneliti masalah ini. Dengan rumusan bagaimana pengaruh aktivitas organisasi terhadap prestasi pengurus BEM Universitas Riau dan apa yang menjadi faktor nya. Tujuan penelitian untuk mengetahui pengaruh aktivitas organisasi terhadap prestasi belajar. Teori yang digunakan adalah teori organisasi, teori interaksi, teori motivasi, teori prestasi dengan menggunakan metode penelitin Kuantitatif Deskriptif. Cara mendapatkan data dengan observasi dan angket. Hasil penelitian ini dapat diketahui pengaruh aktivitas organisasi terhadap prestasi belajar dan faktor-faktor yang mempengaruhinya. Dalam penelitian ini diketahui bahwa aktivitas organisasi memiliki pengaruh positif terhada pengurus yang mengikutinya. Salah satu pengaruh positif yag didapat adalah mampu mengatur waktu antara organisasi dengan kuliah, komunikasi baik. Pengaruh tersebut dipengaruhi oleh beberapa faktor, baik internal maupun eksternal. Faktor internal berasal dari diri seperti orang tua, masas depan, persaingan dan percaya diri. Sedangkan faktor eksternal seperti teman, pola fikir dan pandangan, jiwa kompetisi dan pengalaman organisasi.

Kata Kunci : Aktivitas Organisasi, Prestasi Belajar

\section{PENDAHULUAN}

Organisasi merupakan sebuah sistem yang terdiri dari aneka macam elemen atau subsistem, diantara mana subsistem manusia yang mungkin merupakan subsistem terpenting dan dimana terlihat bahwa masing-masing subsistem saling berinteraksi dalam upaya mencapai sasaran-sasaran atau tujuan ttujuan organisasi yang bersangkutan.

Organisasi dibentuk oleh manusia untuk memenuhi aneka ragam kebutuhannya seperti kebutuhan emosionalnya, kebutuhan spiritualnya, kebutuhan intelektualnya, kebutuhan ekonominy, kebutuhan politiknya, dan sebainya. Pada dasarnya organisasi memiliki ciri yang mendasar yakni adanya orang-orang dalam arti lebih dari satu orang, ada kerja sama da nada tujuan.

Secara umum definisi organisasi dibedakan menjadi tiga, yaitu : pertama, organisasi dipandang sebagai kumpulan orang, kedua, organisasi dipandang sebagai proses pembagian kerja, ketiga, organisasi dipandang sebagai sistem. Organisasi sebagai sekumpulan orang maksudnya organisasi terdiri dari orang-orang dan kelompok baik besar maupun kecil, dimana orang-orang ini adalah makhluk hidup yang berjiwa, berfikir dan berperasaan yang menciptakan organisasi untuk mencapai tujuan mereka.

Organisasi sebagai proses adalah didalam organisasi adanya proses pembagian 
kerja, karena organisasi meliputi struktur yang menentukan hubungan resmi orangorang dalam organisasi. Dimana orang-orang ini melakukan pekerjaan yang berbeda untuk mendukung semua aktivitas organisasi.

Sedangkan organisasi sebagai sistem karena terdiri dari bagian-bagian yang saling berhubungan dan saling tergantung dan diatur sedemikian rupa sehingga menghasilkan suatu kesatuan. Setidaknya ada empat persyaratan pokok dalam membuat suatu organisasi : lebih dari satu orang yang mempunyai kebutuhan atau tujuan yang mereka tidak dapat memenuhi kehidupan sendiri, mereka harus memiliki suatu yang dapat disumbangkan kedalam organisasi, adanya suatu tempat dimana mereka berkumpul, keterkaitan antara orang, sesuatu yang disumbangkan dan tempat dimana organisasi itu akan dibentuk.

Perbedaan pandangan antara mahasiswa tentang organisasi menarik perhatian peneliti untuk meneliti apakah benar organisasi berpengaruh buruk terhadap prestasi belajar mahasiswa atau malah sebaliknya organisasi membawa dampak baik terhadap prestasi belajar mahasiswa.

\section{Kerangka Dasar Teori}

Organisasi merupakan suatu wadah dimana kegiatan interaksi sosial dilakukan atau dapat diartikan sebagai proses dimana terjadi interaksi antara orang-orang yang ada didalam organisasi. Organisasi dibentuk karena ada keinginan dari dua orang atau lebih untuk memenuhi kebutuhan hidupnya. Hakikat organisasi bukan hanya alat untuk memenuhi kebutuhan hidup manusia secara lahiriah atau material saja, tetapi organisasi juga sebagai tempat berkarya dan juga sebagai sarana aktualisasi diri dari setiap anggota yang ada didalamnya.

Menurut Robbins (2003;5)organisasi merupakan kesatuan (entity) sosial yang dikoordinasikan secara sadar, dengan sebuah batasan yang relative terus menerus untuk mencapai suatu tujuan bersama atau kelompok tujuan.

Organisasi itu ada untuk Mencapai tujuan-tujuan, kemudian seseorang (pemimpin) harus menetapkan tujuan-tujuan tersebut dengan alat atau cara yang dapat digunakan untuk mencapai tujuan tersebut. Selanjutnya Fathoni (2005: 20) menyatakan pada dasarnya organisasi memiliki ciri yang mendasar yakni adanya orang-orang dalam arti lebih dari satu orang, adanya kerja sama, dan adanya tujuan.

Interaksi Sosial adalah hubungan timbal balik antara dua orang atau lebih yang berperan saling memengaruhi antara individu dan individu, antara individu dan kelompok, dan antara kelompok dengan kelompok. Interaksi sosial merupakan proses setiap orang menjalin kontak dan berkomunikasi dan saling memengaruhi dalam pikiran maupun dengan tindakan. Interaksi sosial sebagai pondasi dengan sebuah tindakan yang didasarkan ada norma dan nilai sosial yang berlaku dan diterapkan dalam masyarakat.

Berlangsungnya interaksi sosial dengan baik jika aturan-aturan dan nilai-nilai dilakukan dengan baik. Jika tidak adanya kesadaran dari masing-masing, maka proses sosial pun tidak akan berjalan dengan yang diharapkan.

Menurut Horton Cooley (2001:100) mengatakan bahwa interaksi sosial merupakan pantulan apa yang dirasakan sebagai tanggapan masyarakat terhadap dirinya. Motivasi merupakan pendorong utama perilaku seseorang dalam suatu pekerjaan. Seorang pekerja menjadi rajin atau tidak rajin, kreatif atau tidak kreatif, dapat ditelusuri lewat motivasi yang ada di dalam dirinya. 
Perhatian serius pada masalah motivasi membuat pimpinan di suatu organisasi dalam memanfaatkan motivasi di dalam diri tiap pekerja untuk mencapai tujuan perusahaan.

Menurut Herzberg (2012) Teori yang dikembangkannya dikenal GHQJDQ ${ }^{3}$ ORGHO 'XD )DNWRU¥ GDUL motivasi, yaitu faktor motivasional dan faktor hygiene Menurut teori ini yang dimaksud faktor mvasional adalah hal-hal yang mendorong berprestasi yang sifatnya intrinsik, yang berarti bersumber dalam diri seseorang, sedangkan yang dimaksud dengan faktor hygiene atau pemeliharaan adalah faktor-faktor yang sifatnya ekstrinsik yang berarti bersumber dari luar diri yang turut menentukan perilaku seseorang dalam kehidupan seseorang.

Menurut Herzberg, yang tergolong sebagai faktor motivasional antara lain ialah pekerjaan seseorang, keberhasilan yang diraih, kesempatan bertumbuh, kemajuan dalam karier dan pengakuan orang lain. Sedangkan faktor-faktor hygiene atau pemeliharaan mencakup antara lain status seseorang dalam organisasi, hubungan seorang individu dengan atasannya, hubungan seseorang dengan rekan-rekan sekerjanya, teknik penyeliaan yang diterapkan oleh para penyelia, kebijakan organisasi, sistem administrasi dalam organisasi, kondisi kerja dan sistem imbalan yang berlaku. Prestasi belajar atau hasil belajar (achievement) yang merupakan realisasi atau perkara dari kecakapan-kecakapan potensial atau kapasitas yang dimiliki seseorang. Menurut Siti Pratini (2005) prestasi belajar adalah suatu hasil yang dicapai seseorang dalam melakukan kegiatan belajar.

Sedangkan menurut Sumadi Suryabrata (1998) prestasi belajar adalah nilai sebagai rumusan yang diberikan seseorang mengenai kemajuan atau prestasi belajar selama masa tertentu.

\section{METODE PENELITIAN}

Metode Penelitian Metode penelitian yang digunakan dalam penelitian ini adalah kuantitatif deskritif penelitian ini akan menggambarkan dan menganalisa kondisikondisi atau peristiwaperistiwa yang terkait dengan permasalahan yang diajukan, selain itu sesuai dengan jenispenelitian ini, maka jenis data yang akan penulis gunakan adalah data-data kuantitatif.

Teknik pengumpulan data adalah suatu cara khusus yang digunakan peneliti dalam menggali data dan fakta yang diperlukan dalam penelitian. Adapun teknik yang digunakan dalam pengumpulan data pada penelitian ini yaitu :

Observasi meupakan pengamatan langsung dilapangan untuk memperoleh data yang berkaitan dengan permasalahan didalam penelitian ini. penelitian melakukan pengamatan dengan menggunakan indera penglihatan tidak dengan mengajukan pertanyaan-pertanyaan.

Penelitian ini peneliti dibantu oleh alat bantu dokumentasi yaitu menggunakan kamera foto, dan alat perekam suara (recorder). Kamera foto digunakan untuk merekam kejadian-kejadian yang peneliti temukan dilapangan.

Sedangkan perekam suara digunakan untuk merekam percakapan wawancara dengan informan penelitian di lapangan.

Teknik angket yaitu teknik yang digunakan untuk mengumpulkan data dengan pertanyaan yang ditujukan kepada responden yang berisi pertanyaan-pertanyaan yang berkaitan dengan permasalahan yang akan ditelitidengan menyebarkan angket atau kuisioner kepada responden dilapangan. 
Dalam penelitian ini peneliti menggunakan metode deskiptif kuantitafif, maka demikian dirasa perlu dalam metode angket ini peneliti menggunakan dua sitem angket yaitu tertutup dan terbuka guna mendapatkan kejelasasan dari pertanyaan yang diberikan dalam kuisioner.

Kuisioner tertutup yaitu pertanyaan yang jawabannya sudah ditetapkan oleh peneliti sedangkan kuisioner terbuka adalah kuisioner yang berisikan pertanyaan yang jawabannya diberikan hak penuh untuk menjawab pertanyaan-pertanyaan dalam kuisioner.

Pada penelitian ini penulis membatasi ruang lingkup penelitian, dimana penelitian ini dilakukan di BEM Universitas Riau denga lingkup peneliti tentang pengaruh Aktivitas Organisasi dan Faktor yang mempengaruhinya.

\section{HASIL DAN PEMBAHASAN}

Keaktifan dalam Organisasi BEM Universitas Riau Berkembangnya organisasi harus didukung dengan daya dukung sumber daya manusia yang kuat. Karena dalam komponen sebuah organisasi faktor yang mendominasi dalam melakukan sebuah organisasi adalah orang-orang yang berada dalam organisasi tersebut.

Semakin aktif pengurus sebuah organisasi maka akan semakin berjalan dengan bagus organisasi yang didirikan. Begitu pula sebaliknya, semakin buruk sumber daya manusia yang dimiliki maka akan semakin buruk sebuah organisasi. Untuk itu dalam tabel ini dirasa perlu memperlihatkan keaktifan pengurus BEM Universitas Riau dalam kegiatan sehari hari.

Tingkat keaktifannya dibanding dengan pengurus perempuan dibuktikan dengan hanya 1 orang pengurus laki-laki dari 22 pengurus yang aktif dalam orrganisasi BEM Universitas Riau. Hal lain yang menjadikan pengurus wanita lebih banyak dibandingkan dengan pengurus laki-laki disebabka dengan tanggung jawab pengurus perempuan lebih tinggi daripada pengurus laki-laki mengenai tugas piket kesekretariatan yang diberikan oleh kementerian sekretaris kabinet.

Keaktifan seorang pengurus organisasi selain dengan aktivitas keseharian juga didukung dengan intensitas kehadiran pengurus organisasi ke sekretariat BEM Universitas Riau.

Pengaruh Organisasi terhadap Prestasi Pengurus segala aktivitas yang dilakukan seseorang pasti memiliki dampak atau pengaruh yang ditimbulkan dari kegiatannya, begitu dengan aktivitas organisasi. Aktivitas organisasi memiliki pengaruh terhadap seseorang yang mengikuti organisasi tersebut, baik pengaruh yang positif maupun pengaruh negatif. Pengaruh terhadap tingkah laku, kedisiplinan, pola berfikir, tata kelakuan dan tindakan maupun pengaruh pada prestasi pengurus tersebut didalam belajar.

Pada tabel selanjutnya akan sama-sama diketahui seberapa pengaruh yang dilakukan oleh aktivitas organisasi terhadap prestasi belajar pengurus yang dimulai dari tabel 1 berikut ini :

\begin{tabular}{cccc}
\hline No & $\begin{array}{c}\text { Alternatif } \\
\text { Jawaban }\end{array}$ & Frekuensi & Pensentase \\
\hline 1 & Ya & 50 & 91,2 \\
2 & Tidak & 7 & 8,8 \\
& Jumlah & 57 & 100 \\
\hline
\end{tabular}

Sumber: Data Diolah, 2017 
Hasil dari data yang disajikan diatas menjelaskan bahwa organisasi memiliki pengaruh terhadap prestasi belajar yang dimiliki oleh setiap pengurus, memang tidak dipungkiri setiap aktivitas yang dilakukan oleh organisasi menimbulkan efek terhadap setiap pelaksananya. Efek tersebut dapat dirasakan dalam jangka waktu yang dekat dan dalam jangka waktu yang lama. Dalam jangka waktu dekat biasa yang ditimbulkan oleh organisasi adalah perubahan akan sikap, tingkah laku serta kepribadian yang mendorong pengurus bersifat dewasa dalam menghadapi setiap tantangan dalam menjalankan aktivitas organisasi yang dilaksanakan. Dalam jangka waktu yang cukup lama diketahui hasilnya adalah proses belajar yang berdampak terhadap indeks prestasi yang dibuat oleh pengurus organisasi tersebut.

Pengaruh yang ditimbulkan dalam jangka waktu yang dekat yang pertama dilakukan adalah bagaimana pengurus dapat mengkondisikan dan dapat menyesuaikan waktu terhadap aktivitas yang dilakukan oleh pengurus organisasi baik aktvitas perkuliahan maupun aktivitas organisasi.

Dalam tabel selanjutnya akan mengetahui seberapa banyak pengaruh yang ditimbulkan aktivitas organisasi terhadap aktivitas keseharian pengurus organisasi .

\begin{tabular}{|c|c|c|c|}
\hline No & $\begin{array}{c}\text { Alternatif } \\
\text { Jawaban }\end{array}$ & Frekuensi & Pensentase \\
\hline 1 & $\begin{array}{l}\text { Sangat } \\
\text { setuju }\end{array}$ & 14 & 24,6 \\
\hline 2 & Setuju & 22 & 38,6 \\
\hline 3 & Netral & 21 & 36,8 \\
\hline 4 & $\begin{array}{c}\text { Kurang } \\
\text { Setuju }\end{array}$ & 0 & 0 \\
\hline
\end{tabular}

\section{Sumber: Data diolah, 2017}

Hasil dari data diatas menjawab pertanyaan bahwa penguruus dapat menyesuaikan keadaan terhadap setiap aktivitas yang dilakukan, baik aktivitas organisasi maupun aktivitas perkuliahan yang dilakukan oleh pengurus organisasi. Hal ini dibuktikan dengan persentasi jawaban yang diberikan tabel diatas tidak ada yang tidak setuju mengenai pengurus yang tidak bisa mensiasati waktu antara aktivitas organisasi maupun aktivitas perkuliahan. Hal ini disebabkan karena pengurus memiliki cara masing masing dalam membagi waktu dalam menjalankan aktivitasnya.

Pengaruh yang ditimbulkan oleh tidak mampunya pengurus dalam mengatur waktu juga akan dapat berdampak didalam aktivitas belajar pengurus organisasi, dimana ketika aktivitas belajar yang dilakukan oleh pengurus organisasi terganggu, maka akan secara otomatis hasil yang didapat juga akan terganggu. Baik secara indeks prestasi maupun secara mental. Berdasarkan hasil tabel diatas menerangkan bahwa pengurus tidak setuju mencapai sebanyalk 19 responden atau 33,3 \% dari responden. Ini disebabkan mereka tidak menemukan kendala ketika bekerjasama antara satu dengan yang lain.

Hal utama yang menyebabkan ketidak adanya kendala ialah kerjasama yang kompak serta komunikasi yang lancar guna memperjelas hal yang dilakukan. Selanjutnya 36 orang responden atau 63,2 \% menyatakan kurang setuju karena mereka menganggap bahwasannya membangun kerjasama tidak menjadi permasalahan besar, komunikasi yang lancar yang menjadi panduan utama agar tidak adanya kesalah pahaman antara pengurus satu dengan pengurus lain. Tak dipungkiri mereka sesekali menemukan kendala dalam 
melakukan kerjasama yang disebabkan oleh kurangnya koordinasi antara pengurus satu dengan pengurus lain, namun ini juga tidak dijadikan sebagai penghambat bagi menciptakan sebuah tim yang kompak dan solid demi terciptanya kerjasama yang diinginkan oleh suatu tim. Sedangkan bagi mereka yang memilih netral sebanyak 1 orang mengatakan bahwa ia merasa berada posisi ketika ia sedang berada pada posisi yang ia paham, maka ia akan mudah untuk bekerjasama antara satu dengan yang lain, semantara ketika ia tak paham akan tugas yang diberikan ia merasa kesulitan karena ia tak mengetahui bagaimana ia memulai tugasnya yang berakibat terhadap susahnya bekerja sama terhadap pengurus yang lain.

Organisasi bukan hanya berbicara tentang komunikasi yang baik dan kerjasama yang baik, selain itu dalam berorganisasi juga menimbulkan daya saing untuk saling berpacu dalam menggapai prestasi Pemicu utama dalam meningkatkan prestasi dimulai dengan adanya motivasi.

Motivasi itu sendiri adalah keadaan dalam pribadi seseorang yang mendorong keinginan individu untu melakukan kegiatan-kegiatan tertentu guna mencapai suatu tujuan. Motivasi bukanlah sesuatu yang dapat diaamati, tetapi merupakan hal yang dapat disimpulkan adanya karena sesuatu yang tampak. Motivasi merupakan masalah yang kompleks dalam organisasi karena kebutuhan dan keinginan setiap anggota organisasi adalah berbeda-beda. Dan berkembang atas dasar proses belajar yang betbeda pula. Motivasi dapat ditimbulkan baik oleh faktor internal maupun eksternal tergantung bagaimana dan darimana suatu kegiatan dimulai. Kebutuhan dan keinginan yang ada dalam diri seseorang akan menimbulkan motivasi internal. Begitu juga dalam organisasi, setiap individu akan mempunyai kebutuhan dan keinginan yang berbeda dan unik.

Motivasi yang dimaksudkan oleh responden yang mengatakan sangat setuju sebanyak 27 orang atau 47,4 \% dari responden yang mengatakan bahwa motivasi ia muncul melalui diri sendiri dan lingkungannya. Motivasi dari diri seperti mempertahankan pendapat diri dan memperkuat dirisedangkan motivasi yang berasal dari lingkungan adalah dapatnya bimbingan dari teman teman sekitar dalam meningkatkan kepercayaan diri dan teman yang mengajarkan terhadap teman yang tidak mengetahui. Resoponden yang menjawab setuju sebanyak 29 atau 50, $9 \%$ dari responden yang mengatakan bahwa motivasi berasal dari dua faktor yaitu faktor diri sendiri dan faktor yang dipengaruhi orang lain maupun lingkungannya.

Faktor diri sendiri lebih kepada kasih sayang yang diciptakan kepada diri untuk menciptakan sebuah keharmonisan. Sedangkan motivasi yang berasal dari orang lain atau lingkungan adalah motivasi yang dipengaruhi oleh keseharian kelompok pada saat bersama, dimana motivasi itu muncul ketika saling memberikan semangat dukungan serta dorongan untuk menjadi suatu hal yang baik.

Hasil dari proses belajar yang ditimbulkan adalah indeks prestasi yang didapat ketika semester selesai setelah melaksanakan ujian. Apakah dengan pengaruh yang dilakukan oleh aktivitas organisasi berpengaruh terhadap indeks prestasi yang didapat oleh pengurus BEM Universitas Riau.

\section{KESIMPULAN}

Berdasarkan hasil penelitian dan pembahasan, maka dapat ditarik kesimpualan sebagai berikut : 
1. Aktivitas organisasi memberikan dampak positif terhadap prestasi belajar Pengurus BEM Universitas Riau dibuktikan dengan indeks prestasi pengurus yang meningkat saat mengikuti BEM Universitas Riau

2. Aktivitas organisasi memberikan dampak positif terhadap pengurus BEM Universitas Riau dibuktikan dengan kemampuan fisik dan mental pengurus BEM yang dapat mengatur waktu, komunikasi yang baik, serta meningkatkan jiwa persaingan yang tinggi serta meningkatnya peraya diri terhadap kemampuan yang dimiliki oleh setiap pengurus BEM Universitas Riau

3. Organisasi memberikan dampak melalui beberapa faktor, baik yang ditimbukan oleh diri sendiri maupun faktor yang berasal ari orang lain. Faktor yang berasal dari diri sendiri atau sering disebut dengan faktor internal antara lain orang tua,masa depan, persaingan yang semakin ketat, teman dan kepercayaan diri. Sedangkan faktor yang ditimbulkan dari luar diri sendiri atau faktor eksternal seperti lingkungan, teman, pola fikir dan pandangan yang semakin dewasa akibat pergaulan yang ditimbulkan oleh teman organisasi, cara membagi waktu antara kuliah dengan organisasi, semangat yang diberikan teman, jiwa kompetisi dalam meraih prestasi, serta pengalaman organisasi yang dijadikan sebagai pembelajaran.

\section{DAFTAR PUSTAKA}

Bungin Burhan. 2011. Metodologi Penelitian Kuantitatif. Cetakan Kedua. Jakarta: Kencana Prenada Media grup.

Fathoni, Abdurrahmat. 2005. Organisasi dan Manajemen Sumber Daya Manusia. Jakarta : PT Raja Grafindo Persada.

Fathoni, Abdurrahmat. 2006. Organisasi dan Manajemen Sumber Daya Manusia. Jakarta : Rineka Cipta.

Maryani Kun. 2001. Sosiologi Jilid I. Jakarta : Erlangga.

R. Siti Maryam. 2008. Mengenal Usia Lanjut dan Perawatannya. Jakarta : Salemba Medika Robin P, Stephen. 2003. Perilaku Organisasi. Jakarta : PT Indeks Kelompok Gramedia.

Saepul Hamdi Asep. 2012. Metode Penelitian Kuantitatif, Revisi ke Dua. Yogyakarta : CV Budi Utama.

Pratini Siti. 2005. Psikologi Pendidikan. Jakarta : Raja Grafindo

Soekanto Soerjono. 2012. Sosiologi Suatu Pengantar, Cetakan Ke Empat Puluh Empat. Jakarta: PT Raja Grafindo Persada.

Soekanto Soerjono. 1990. Pengantar Sosiologi,Cetakan Keempat. Jakarta:PT Raja Grafindo Persada.

Suryabrata Sumadi. 1998. Psikologi Pendidikan. Yogyakarta: Stunding.

Sunarto Kamanto. 2004. Pengantar Sosiologi. Cetakan ketiga, Jakarta, Penerbit fakultas Ekonomi. 
Sutarto. 2006. Dasar \pm Dasar Organisasi. Yogyakarta: Gadjah Mada University Press.

Tampubolon P. Manahan. 2004. Perilaku Keorganisasi, Jakarta : Ghalia Indonesia,

Thantaway.2005. Kamus Istilah Bimbingan dan Konseling, Jakarta : Kanisius

Thoha Miftah. 2005. Perilaku Organisasi : Konsep Dasar dan Aplikasinya, Jakarta : PT Raja Grafindo Persada.

Winardi. 2006. Teori Organisasi dan Pengorganisasian, Jakarta : PT Raja Grafindo Persada. 